\title{
Augustus' power from the stars and the foundation of Augusta Praetoria Salassorum
}

\author{
Stella Vittoria Bertarione and Giulio Magli
}

\begin{abstract}
Augustus' propaganda founded the ruler's power on a series of references to the sky: Caesar's comet, which helped establishing the divine nature of kingship, the completion of the calendar's reform celebrated in the Campus Martius' meridian, and Augustus' association with the Capricorn, the zodiacal sign of the winter solstice. A variety of proofs coming from texts, works of art and numismatics show the key role of such a "power from the stars". We present here new archaeological and archaeoastronomical evidences coming from Augusta Praetoria Salassorum (modern Aosta), founded around $25 \mathrm{BC}$ after the victory of Augustus' army on the Salassi. An emergency excavation along the Aosta's Roman walls has indeed brought to light a block in situ on a corner of one of the towers which carries several reliefs - including a plough and a spade - apparently related to the town's foundation ritual. As a consequence, we carried out a complete analysis of the original urban plan of Aosta and of its relationship with the sky and the landscape, taking into account the complex natural horizon of the Alps in which Aosta's valley is nested. The results show that the town was oriented in such a way as to pinpoint Augustus' "cognitive" relationship with the "cosmic" signs of renewal.
\end{abstract}




\section{Introduction}

Throughout a long but inexorable process, Gaius Octavius (September 23, 63 BC August 19, 14 AD) was to become Augustus, Imperator Caesar Divi Filius, the first of the Roman emperors. It is very well known that Augustus' power - auctoritas was based on a intelligent use of propaganda and that a fundamental ingredient of such a propaganda was related to the stars and to the identification of the ruler with the keeper of the celestial cycles. Augustus credited himself as the harbinger of a new "golden" era, forewarned at his putative father's death by the appearance of the Sidus Julium (Caesar's comet) and profoundly connected with the tradition of the mythical origins and foundation of Rome (Zanker 1990).

As we shall review in Section 6, this mechanism is very well attested in the written sources, in the artistic iconography and in Numismatics. However, of course, hints to this scenario have to be expected also in monumental architecture, and therefore we would expect Archaeoastronomy (and, more generally, astronomical symbolism) to play a role in the interpretation of the Augustan building programme. Up to now, the archaeological records which explicitly hint at Augustus' "celestial" power are mainly the remains of the meridian in the Campus Martius. The original, extensive interpretation of these remains in terms of a complex architectural, sun-related project with the Ara Pacis (Buchner 1976) has been, however, re-assessed by later studies (Heslin 2007, Hannah 2009, Haselberger 2011). It is also true that the Pantheon has been shown to be a building intimately connected with the celestial cycles, since a spectacular hierophany starts there at the spring equinox and reaches its maximum on the day of the foundation of Rome (Hannah 2009, Hannah and Magli 2011), but these results hold for the presently visible, Hadrianic version, and much debate exists on how the original structure conceived by Agrippa looked like. Other places where an archaeo-astronomical confirm of the Augustan "stellar" iconography might be naturally searched for are, however, the towns founded by Augustus.

One of the most paradigmatic Augustan towns under all respects is Augusta Praetoria Salassorum (modern Aosta). Aosta was never subjected before to a archaeo-astronomical analysis; the research here presented started in winter 2012 when, during emergency excavation operated by the Aosta Superintendence to Cultural Heritage along the city walls, an unexpected archaeological discovery occurred. It is a sculpted corner block in situ on one of the walls' towers. The carvings on the block include, among others, a plough and a spade; the sculpture immediately appeared, therefore, to be related to the foundation of the town, so to give first hand information on such key moments. We present here a detailed analysis of this discovery as well as of the accurate archaeoastronomical investigation of the urban town plan which followed. Such a study takes into account the (practically 
intact) ancient landscape in which the town was located and thus, in particular, the stunning horizon of the Alps which surrounds the town's valley. Our results pinpoint at Aosta as a key example from the Roman world of a "city of the founder". In Aosta's project Augustus' associations with the "cosmic" signs of renewal - the winter solstice and the Capricorn - appear indeed to have been harmoniously embodied. These results are framed in a coherent picture - which includes the new archaeological records, the existing sources, and the archaeoastronomical analysis along the way of the modern, inter-disciplinary approach to Archaeoastronomy.

\section{Augusta Praetoria and the excavations at the Balivi Tower}

As is well known, the urban plan of the Roman cities followed a regular scheme. At least from the 3 th century $\mathrm{BC}$ onward indeed, the city walls formed a rectangle, with the internal streets organized as a orthogonal grid (Castagnoli 1971,Torelli and Gros 1988, Laurence, Cleary and Sears 2011). The grid was divided into four quarters by the two main roads, which are customary called Decumanus Maximus and Kardo Maximus although, strictly speaking, ancient sources use this terminology only in the rural context. The centre of social and religious life was preferably placed at (or near) the intersection of these main roads.

Aosta can be considered as a paradigm of this kind of urban layout (Fig. 1). The city was founded by the Roman Army in 25 BC shortly after the war on the Salassi, the original inhabitants of the region, who threatened the way towards Galliae trough the Great and the Little S. Bernardo mountain pass. In Laurence, Cleary and Sears (2011, p.51) words, the foundation of Aosta "marked a transformation of the place from wild mountains associated with dangerous enemies, into a sacred landscape of victory". Especially owing to the series of archaeological studies by Rosanna Mollo (Mollo 1982a,b; 1987, 1988, 1994, 1995, 1999, 2000, 2004, 2012) we have a quite detailed understanding of the Roman town, of which much has been preserved. The walls' circuit is perfectly rectangular, with sides of $725 \times 571$ meters. Towers guarded the corners, the gates and the sides for a total of 20 . One of the 4 main gates, the eastern one or Porta Praetoria, survives almost intact and is a masterpiece of Roman architecture; nearby lies the equally famous theatre, with the southern façade $22 \mathrm{~m}$ tall. The heart of the town was in the forum, a rectangular marketplace surrounded by a covered portico and hosting at the centre two twin temples built on a raised terrace. These twin temples were almost certainly devoted to deified Rome and to Augustus, respectively. Although the occurrence of Capitolia as main temple in newly founded towns has been recently shown to be not a rigid rule as was instead commonly believed (Wilson and Quinn 2013), the temple's dedications anyhow appear as a clue to the profound and intimate connection between the town and her virtual creator. 
Indeed, as is well known, while Augustus discouraged the cult of his personality inside Rome, it was not the same outside the capital; in Aosta veneration and celebration of the founder are apparent not only in the city name and her temples but also in other monuments, which include a triumphal arc built along the Decumanus' axis. In this respect new, unexpected connections emerged after the recent excavation of the so-called Balivi Tower (Fig. 2). This tower is located at the north-east corner of the circuit and bears her name from the Balives, the city officials who resided there during the Middle Age. In 2012, the Superintendence operated an emergency excavation due to the planned construction of a electric substation device along the tower's foundation. The excavations brought to light the foundation layers of the building up to the sterile soil. The tower turned out to rest on a circular platform of stone pebbles held together by a tenacious white mortar and built with the help of radial sectors. The platform is contemporary with the foundation layer of the Roman wall, the latter being made of well refined travertine blocks. The Roman layers are preserved almost everywhere up to the $5^{\text {th }}$ course. Above the latter starts a different masonry composed of 12 courses of greater blocks, at least some of which are in second use and come from the Roman theatre nearby. This section pertains to a restoration documented in the Middle Age around the $12^{\text {th }}$ century.

The Roman courses were already under the terrain level when these additions were made, since the offset indicating the Middle Age terrain level is clearly visible. There is, therefore, no doubt whatsoever - both architecturally and stratigraphycally - that the travertine courses recently brought to light are intact and pertain to the first phase of the city walls. Unexpectedly, when the block located at the fifth course on the south-east corner of the tower was exposed it revealed an elaborate series of reliefs (Fig 3). As mentioned, the block is in situ; moreover it was originally in plain view, since the Roman street level is around one meter below; it is probably because the basis of the tower was flooded and covered by alluvial material in the early Middle Age, that most of the carvings were saved from vandalism and iconoclasty. The technique adopted to sculpt the block is high relief and therefore, again, there is no doubt that the carvings are in the original position and pertain to the first phase of the walls (actually the block was almost certainly sculpted before being put in place, to avoid errors which would have been unrecoverable). The stone occupies a "key" position with respect to the statics of the tower and for this reason it was mounted using L-shaped joints. It is important to stress that, as we have accurately verified on site, the tower is precisely oriented conformally to the walls.

To describe the reliefs on the block we observe that the overall iconography appears to be clearly and intentionally divided into two registers (Fig. 4). The lower register presents two reliefs (denoted with A1 and A2) and both are phallic symbols. The two phalli are depicted in opposite directions and point to the corner of the tower. The 
upper register contains three reliefs, of which $\mathrm{B} 1$ and $\mathrm{B} 3$ are discernible as the representation of the hand-drive of a plough and of a arrow-like object (a spade) respectively. Relief B2 is partly eroded but, as we shall see, it was almost certainly a rampant zoomorphic figure, and the analysis which follows in the next sections will lead us to a quite natural guess for its interpretation as a Capricorn.

\section{Symbols on Roman walls and the meaning of the reliefs on the Balivi tower}

Roman City walls and gates fall within the category of so-called res Sanctce, as any infringement of them would be punished at the same footing of infringement of laws. This of course reflected the sanctitas of the foundation ritual of the town in itself, as an ideal replica of the mythical foundation of Rome (see e.g. Carandini \& Cappelli 2000). The perimeter of the new colony or Sulcus Primigenius was ploughed by coupled oxen driven by priests and assisted by officials, as represented in several reliefs and coins and documented by historians, like Dionysius of Halicarnassus. The ritual - which appears to have been performed in counter-clockwise direction was preceded by the auspices, taken by the augures trough the observation of the flight of the birds. Since the walls were "inviolable" not only practically but also symbolically, the plough was raised in correspondence of the future gates of the town (Rykwert 1999).

Walls and gates were thus to be endowed with "magical" protection, and it is therefore understandable that the wall's Sanctitas could be further emphasized and amplified eloquently by the insertion of symbols on particular points of the perimeter and, in particular, near gates and corners. It is within this context that the presence of sculpted symbols on Roman fortification walls is relatively common. There is no comprehensive catalogue of this kind of artworks, but the documented reliefs can be broadly divided into two main categories: phallic symbols and other symbols (Lugli 1957, Magli 2006).

Phallic symbols are ubiquitous in time and space. They appear already on the walls of early Republican towns of central Italy like Arpino and Ferentino, but we find them also many centuries later, for instance on Hadrian's wall. As mentioned, they are usually placed in key points like projecting angles, towers, and gates. They also occur, however, on houses' walls and public works (e.g. bridges). As is well known, the role of the phallus - which goes back to the Greek Hermae and the Dionysiac tradition - was apotropaic, as a charm associated to a magic defence from external agents. The phallus was the best weapon against evil eye and dangers of various kinds, not to mention its connection with the Dionysiac court and therefore with Priapus as a fertility God.

More rare are the cases in which different subjects appear in the wall's blocks. Also in 
this case, however, the reliefs occur in key points of the structures, such as corners or gates, and are refined enough to let us think that they were especially prepared and carved before being put in place. They were, therefore, expressions of an explicit will of the builders and not extemporaneous carvings. Typically, such reliefs refer to locally important iconographies or deities. A paradigmatic case here is in the town of central Italy called Alatri. Here carved sculptures of divinities appear in blocks set in correspondence of at least 3 gates; they are almost indecipherable today, but were documented in the 19 century in the pioneering survey by Marianna Candidi Dionigi (Candidi Dionigi 1809). Other elaborated symbols occur in the walls of the Alatri Acropolis. One such symbols is a composite, T-shaped figure of 3 phalli, sculpted on the lintel of the postern gate; the other, that most commentators interpret as an eagle, is on the south-east corner stone, at the basis of the most magnificent - and still intact - wall of the entire circuit (Fig. 5). Another (much less known) example can be seen in the polygonal wall enclosure of Grotte di Torri, near Sabina (province of Rieti) (Fig. 6). The site is a huge, squared settlement on the top of a hill not far from the ancient Cures Sabini, likely dated to the second century BC. Here, on the north-west corner, we find again a corner block in situ carrying significant reliefs. On the northwest face an heraldic animal is present; today it is partly eroded but it was certainly a lion, as documented in the $19^{\text {th }}$ century (Giovenale 1899); on the other visible face an elaborate symbol of 3 phalli is still visible; further, as in Aosta, single phallic reliefs occur at a lower level.

The reliefs discovered in Aosta belong therefore to a standing tradition. In particular, the iconography of the lower register is of course immediately referred to the standard apotropaic function of magic protection, as both its reliefs are phallic symbols. As mentioned, the two phalli are in opposite directions and point to the corner of the tower, ideally the point of maximal stress endowed into the walls (A1 and $\mathrm{A} 2$ ).

The iconography of the upper register is, instead, quite complex. We consider first the two reliefs which are almost intact, as they leave pretty little doubt about what they refer to. Relief B1 is in fact easily recognized as a quite standard representation of the governing device of a plough. We are, therefore, very likely in presence of a reference to the sulcus primigenius and the foundation of the town, and we know that such a religious ritual was especially highlighted in Augustan times. For instance, the motif of the ritual ploughing (with a plough virtually identical to the Aosta one) appears in coins of Caesaraugusta and of Merida, both founded in the same period as Aosta (Fig 7).

Reference of the reliefs to the foundation of the town is confirmed by the other, arrow-like image B3, which represents a spade. It might be identified as the ploughshare which was indeed spade-like. There is also a more fascinating, 
equivalently feasible solution, which would anyhow clearly speak about the foundation moments. In fact, as is well known the Roman surveyors used an instrument called groma. The groma was essentially a vertical pole with a bracket device on the summit. At the bracket upper end a squared cross was mounted, carrying a plumb line hinging vertically at each end. Using the groma the Roman surveyors achieved a very high precision, as shown, for instance, by the centuriation of Africa (Chevallier and Caillemer 1954, Decramer and Hilton 1998, Decramer, Hilton and Plas 2001). To work correctly, the groma had to be very stable, and therefore the pole was firmly driven into the terrain with a spade. A famous representation of a groma is that appearing on the tomb-slab of the gromaticus Popidius Nicostratus from Pompeii where the groma's spade looks very similar to the object represented on the Aosta relief (Fig. 8).

The above mentioned reliefs are clearly sufficient to claim that the block recalls the moments of foundation of the town and the tracing of her sulcus primigenius. While the lower, apotropaic reliefs are in converging directions, all the three upper images can be "read" in counter-clockwise direction as was the direction of the first furrow. Further, among all the surviving towers of the town, these reliefs are unique to the Balivi Tower, and this singles out the place as a special one. The same thing is actually true topographically since the tower location corresponds to the highest point (589 meters over sea level) of the plain where the ancient city was built, thus ideal for the survey by the Roman mensores (the circular foundation of the tower is quite unusual, and may lead to suspect a symbolic meaning as well). All in all, it is more than possible that this was the place of the original auguraculum of the town, the place where the first auspices were taken before starting the foundation procedure. What remains to be investigated is the partially eroded figure B3. To this aim the block has been subjected to a false-color, laser-scanner relief. This procedure of course cannot reconstruct the original figure, nevertheless it shows that the body of the animal has been effectively sculpted away, perhaps in an act of iconoclasty which occurred before the land-filling of the basis of the tower, in the early middle age. What is still visible outlines a zoomorphic figure with forward outstretched paws and a rampant horned head. The presence of the plough behind may lead to think to an ox, but these animals are never represented as rampant, especially in (whether practical or symbolic) ploughing scenes. Further, the missing part could hardly be attributed to a bull or another quadruped because there is no space enough for the rear legs. What can be individuated is rather a slight, elongated trace curved toward the rear of the animal. This leads us to consider another hypothesis, which - as we shall see - is also strongly hinted at by the results of next section: the animal might be a Capricorn. The Capricorn is an imaginary beast, an hybrid between a goat and a fish, having the head and front legs of the goat and the body ending with a fish tail. It was identified 
with a zodiacal constellation already in Babylonian astronomy, from where it filtered into Greek and then Roman zodiacal iconography and mythology (Condos 1997). Several iconographic comparisons roughly contemporary to Aosta can be considered for the Capricorn since, as we shall recall later in details, it was a fundamental icon of Augustus' power. Among these, there are masterpieces like the Gemma Augustea (Fig 9) but also more rough representations which are associated with the legions who adopted it as an emblem (or one of their emblems) (Pollard and Berry 2012). Among these, one of special relevance here is Legio II Augusta, documented since 30BC and stationed in the north of Hispania Tarraconensis (Fig 10). This legion was later moved into Germania, but probably not before the Teutoburg defeat (later it was utilized in invasion of Britain by Claudius). II Augusta was in charge of the foundation of Julia Augusta Arausio (Orange), where the Capricorn can be seen on the shields of the legionaries depicted on the north frieze of the decoration of the triumphal arc. We notice, by the way, that although ancient sources do not report the name of the Legio in charge of the war on the Salassi and the foundation of Aosta, Legio II Augusta (or a detachment of troops from it) is a possible candidate. Another context where we can find useful comparisons is, again, Numismatics. The Capricorn indeed appears in many coins of Augustan age (Fig. 11). Coins were an handful way of circulating imperial ideology, and the Capricorn is represented as rampant, bringing (or "protecting") the clipeus virtutis, a star, or a cornucopia. Sometimes, Capricorn substitutes Augustus himself, as in coins having Livia or a an allied king on the recto. Interestingly enough, the case for a Capricorn and a plough depicted together also occurs. The two subjects indeed appear in coins bearing special countermarks, that is superimposed incisions used to reconfirm the validity of money issued by previous authorities. The expedient of countermarks was widespread and useful to ensure the validity of money even in lands hardly reachable by fresh emissions. In such a context many cases are known characterized precisely by the combination of a Capricorn (the top level) below which it is stretched an object identifiable with a plough (Martini 2002, 2003). Such countermarks are added to "restitution coins" by Augustus himself as well as on coins issued by Agrippa, Tiberius and Claudius, the latter two probably with propagandistic aims. (Fig 12)

\section{The orientation of the urban layout of Aosta}

According to a variety of ancient sources, Roman city and land planning involved procedures inherited from the Etruscans and closely connected with the celestial cycles. Indeed, the town's foundation ritual is described by Roman historians (such as Varro, Plutarcus and Pliny the Elder) as a rule directly inherited from the Etruscan's sacred books of the aruspexes, the Disciplina. A fundamental part of the aruspexes 
ritual was connected with the cosmic order, since for the observations of the birds bringing good (or bad) omens from the auguraculum it was first necessary the individuation of a terrestrial, orientated image of the heavens; as a consequence, a role for astronomy has to be expected in the orientation of the Roman towns (Le Gall 1975, Aveni and Romano 1994). In spite of this, attempts at establishing a common rule have been doomed to failure up to now due both to methodological issues and to the practical mentality of the Romans, which in many cases appears to have overruled symbolic principles in favour of local (e.g. geo-morphological) considerations (Magli 2008, Gonzalez Garcia and Magli 2013). However, deliberate astronomical orientation can actually be documented in (many) specific cases, as we shall review in next section. We are thus lead to explore if an astronomical symbolism was connected with the foundation and the project of Aosta.

Aosta lies at some 600 meters on sea level, nested like a jewel in the valley which bears her name. Prominent mountains dominate the landscape. In particular, the horizon to the east is occupied by the Monte Emilius ridge which raises as much as 3000 meters at less than $9 \mathrm{Kms}$ from the center of the ancient town. The layout of Aosta roughly follows the topography of the valley, but there was no special compelling constraint on the specific orientation of the axes; further, the terrain was not level and the axes do not follow the level surfaces so huge works were necessary at the moment of laying the building's blocks of the city. Since the horizon is so complex, for our data we have used a double-blind method, based on a on-site transit survey with the horizon sampled at $1 / 2$ degree intervals. The data have been reported in a spreadsheet database and from the data we obtained the graph reported in (Fig 13). The curve therefore reproduces the eastern horizon with altitudes in degrees. For safety, all data have been validated with geo-referenced measures taken from Google Earth, since the Aosta region is mapped with high accuracy on this satellite database. As far as the town's axes are concerned, the Aosta Decumanus bears an azimuth of $68^{\circ} 02^{\prime}$, and the Kardo bears the azimuth $158^{\circ} 06^{\prime}$. The estimated angle is thus of $90^{\circ} 04^{\prime}$. Since the accuracy of these theodolite measures is of the order of $2^{\prime}$, orthogonality of the axes appears to have been kept with very good precision by the ancient surveyors.

Taking into account the height of the horizon, it is readily seen that the sun rises along the Decumanus in the days around June 3 and sets along the same direction in the days around February 19 (Gregorian). In Augustus' time the calendar dates would have been nearly the same, since the Julian calendar was at that time tuned with the Gregorian (the obliquity of the ecliptic has, however, changed a bit). In any case we shall not discuss further on the possible significance of these solar dates (for instance in the Roman calendar) since we are going to show that it is very probably due to a pure chance that Aosta's Decumanus is oriented in this way. Indeed, we are going to 
show that its direction was fixed (by orthogonality) by the solar orientation of the Kardo.

At a first glance, this statement looks as a contradiction in terms, and indeed, the amplitude in degrees spanned by the rising sun with a flat horizon at the latitudes of northern Italy is about $35^{\circ}$ north/south of east. This means that, usually, if the decumanus direction is oriented to the rising sun in some days of the year, the direction orthogonal to it is not. This situation may, however, change drastically if the horizon is very high, since the horizon can "delay" the effective appearance of the sun until it reaches a sensible altitude and consequently, a greater azimuth. Examples of the use of a complex, undulated horizon for (relatively precise) calendrical observations of rising and settings of the sun and the stars exist in classical antiquity; for instance, the stunning horizon at Delphi was likely used to mark calendrical starevents in dates delayed with respect to those of Greek mainland (Salt and Boutsikas 2005, Liritzis and Castro 2013). In the case of Aosta, it is a crucial date of the solar calendar, the winter solstice, to be singled out by the town's orientation. In fact, the winter solstice sun rises with a theoretical azimuth of $125^{\circ}$ but remains behind the mountain ridge to the south-east until it has an altitude of as much as $17^{\circ}$. The azimuth of the sun at this altitude turns out to be very close to that of the Aosta Kardo. To be precise, today the winter solstice sun has an altitude of $17^{\circ} 20^{\prime}$ at this azimuth, while in Augustus' times - due to the slight variation of the obliquity of the ecliptic - the altitude was about 25' greater. These calculations (made with the software StarryNight Pro) show that the sun was rising in almost perfect alignment with the Kardo on the winter solstice of 25 BC (Fig. 14), but also show that the phenomenon is fully enjoyable still today. We were lucky enough to verify this directly at dawn of the winter solstice 2013 (Fig 15).

\section{Astronomical orientations of Roman towns}

It goes without saying that any astronomical orientation can a priori be due to simple chance. We are, however, going to show that a coherent series of different arguments strongly point to a deliberate orientation of the Aosta layout to winter solstice sunrise. From one side indeed, we have Augustus' iconography of power (addressed in the next section) from the other there is a solid evidence showing the existence of nonrandom patterns of orientations of Roman towns, especially related to the solstices (Magli 2008, Gonzalez Garcia and Magli 2013, González García, Rodríguez Antón, and Belmonte 2014). Among the family of Roman towns orientated along a solstitial line, the most relevant comparisons for the present work are:

\section{1) Polygonal walls' enclosures.}


To such cases belong the two buildings mentioned above for their reliefs, namely Alatri and Grotte di Torri. Alatri was originally studied by Aveni and Capone (1985) who discovered many traces of different nature related to its symbolic foundation; in particular, they found that a main alignment to the summer solstice sunrise was incorporated in its project. As far as the monument at Grotte di Torri is concerned, it is poorly studied and awaits a complete excavation; taking precise measures there is difficult because a $19^{\text {th }}$ century building has been constructed over the ancient foundations. We have, however, measured the azimuth of the walls at the corner as $\sim 59^{\circ} / 239^{\circ}$ (data obtained with a magnetic compass corrected for magnetic declination, previously unpublished). This again corresponds fairly well to the azimuth of summer solstice sunrise/winter solstice sunset (the horizon at the site is flat). Yet another example of enclosure orientated along a solstitial line (azimuth $\sim 122^{\circ} / 302^{\circ}$, data by the authors) is the imposing castrum built by the Romans at Pyrgy (today Santa Severa) in the first half of the second century BC near the Etruscan sanctuary of Leucothea.

\section{2) Orientations of late Republican/Julian towns}

An example of astronomical orientation from the Roman world which is of special relevance here is a family of towns founded between the end of the second century $\mathrm{BC}$ and the Octavian period, again having one of the main axis orientated along a solstitial line. Among them (in chronological order) we have Norba, dated at the second half of the second century BC (Magli 2007), Metellinum (present-day Medellin, Spain), founded on 79 BC, Verona, with an urban plan of likely Julian foundation, and Liberalitas Iulia (present-day Evora, Portugal) (Marques de Faria 2001). Another town very precisely oriented to winter solstice sunset is Augusta Raurica (Augst, Switzerland; Laur-Belart 1973, data independently controlled by the authors). According to the inscriptions on his mausoleum in Gaeta, the town was founded by Plancus in $44 \mathrm{BC}$; however the first archaeological evidences are of Augustan age. In any case, interestingly, the solstitial tradition might have been continued by Octavian at Nicopolis, founded in $31 \mathrm{BC}$ in commemoration of the victory at Actium. Indeed, in spite of the clear east-west topography of the narrow isthmus where the town was built, basing on geo-physical prospect ions of the site (Sarris et al. 2010) the Decumanus of Nicopolis appears to be skewed at an azimuth not far from that of midwinter sunrise.

3) The orientation of Merida

A case of special relevance here is certainly that of Emerita Augusta (modern Merida, 
Spain) (Gonzalez Garcia and Costa-Ferrer 2011, Gonzalez Garcia and Magli 2013). The town was indeed probably founded in the same year of Aosta, 25 BC (Mateos Cruz 2001). The azimuth of the town's axis is a few degrees smaller than that of the winter solstice sunset. However, although the horizon is almost composed by low hills, a somewhat relevant peak is located to the south-west of the town, in such a way that the winter solstice sun actually sets in relatively good alignment. Sunset time at the winter solstice is thus anticipated by the presence of the hill in a manner similar to the delayed sunrise time in Aosta on the same day.

\section{4) The centuriations of Carthage.}

When Carthage was conquered, a centuriation was operated, also in view of the deduction of a colony which was not, however, successful (Carandini, 1983). This centuriation is orientated to the summer solstice sunrise, towards the sea. In $29 \mathrm{BC}$ a new centuriation was effected by Legio III Augusta. The new centuriation was superimposed on the preceding one in the area of the town and its surroundings. Interestingly enough, the new centuriation was oriented along the symmetric direction with respect to the east-west; the new azimuth certainly was more adapted to the topography but it was also the azimuth of the winter solstice sunrise on the sea horizon.

\section{Augustus, the Capricorn, and the interpretation of Aosta's orientation}

The above mentioned comparisons strongly support the idea of a deliberate orientation of Aosta to midwinter sunrise. To get more insights into this we need to understand how the winter solstice had a role in Augustus propaganda. Augustus' power was auctoritas - authority, a informal construction based - in principle at least - on voluntary consent (Galinsky 2005). For the construction of such a consent he drew upon every aspect of public Roman life: civic ideology, traditions, and of course religion. For instance, Augustus held the post of pontifex maximus from 12 B.C. onward, and even the title of Augustus, granted by the Senate in 27 B.C. had previously been associated only with gods or sacred objects. In this way, Augustus credited himself as intermediary with the Gods and keeper of the "cosmic" order, according to a tradition coming from the millenarian power of the Egyptian Pharaohs and re-established by the Hellenistic monarchs. Clearly, the foundation of such a doctrine was to be searched for in the sky. The occasion presented itself very early in the form of a celestial sign, since in July of 44 B.C., a comet appeared during the games that Octavian was holding in honour of Julius Caesar (Ramsey and Licht 1997). Octavian was clever enough to turn the Sidus 
Julium in an omen announcing the deification of Caesar and, as a consequence, crediting himself as the son of a God. The celestial omen was also taken to symbolize the beginning of a new "golden" age, of which Octavian was the natural leader. Since "cosmic order" means also regularity of the calendrical cycles, Augustus took great care in completing the Julian reform and associating himself with it. In particular, he heralded the construction of the horologium, the Meridian in the Campus Martius whose gnomon was an Egyptian obelisk coming from the temple of the sun of Heliopolis (today the obelisk is in Montecitorio square).

When parts of the meridian were first excavated, it was reconstructed as a quite complex device, with the shadow of the gnomon projecting diagonally towards the Ara Pacis on Augustus' birthday. Today we know that it was probably a quite simpler instrument from an astronomical point of view, perhaps signalling only the day with the linear projection of the meridian shadow at noon. No doubt, however, it was also an astrological device, since it displayed the position of the sun in the zodiac day by day. Since at the winter solstice the noon shadow is the longest possible, the instrument "naturally" singled out the sign of the winter solstice, namely, Capricorn (actually, since then, precession has moved the solstice in the region of Ophiucus, between Sagittarius and Scorpio).

This leads us to the second fundamental leitmotiv of Augustus "power from the stars", which was precisely the Capricorn. This association occurs in uncountably many occasions: it is mentioned by several historians (for instance Suetonius ), present in many coins of different parts of the empire, and represented in works of art such as the Gemma Augustea (see again Fig 9). The latter is a true masterpiece, certainly belonging to an high-status personage if not to the imperial family. The themes represented are quite complex, but the center of attraction is Augustus, seated in a hieratic posture similar to that peculiar to Jupiter and typical also of some Hellenistic representations of Alexander. A disk containing a star (probably Caesar's comet) with a superimposed Capricorn is fluctuating over him.

As is well known, there is a "unsolved problem" in Augustus association with Capricorn, which originated from Suetonius words "Capricorni, quo natus est" (Aug. 94.I2) since Augustus was actually born on 23 September and therefore in Libra and not in Capricorn (see Barton 1995 and references therein). There have been many attempts to reconcile this two apparently contradictory facts (for instance, noticing that Capricorn could be considered as the sign of conception, or analysing the position of the Moon in Augustus horoscope). Actually, we do not know which strategy was invented by the ruler's astrologers to legitimate Capricorn in Augustus' Horoscope, but what is certain is that Astrology was already at those times an "elastic" discipline and that Augustus' choose to use it to his propaganda aims, to the point that he had is Horoscope published with an edict. 
The use of astrology to legitimate power was already introduced by Hellenistic monarchs, as shown, for instance, by the famous Lion relief located on the Nemrud Dag, the tomb of Antiochos II Commagene (Belmonte and Gonzalez Garcia 2010). With the end of the Republic and the advent of the monarchy, publishing one's horoscope and keeping a personal astrologer came in use as explicit signals of personal power, a custom later followed by many, if not all, Roman emperors. Capricorn was thus used as a logo, which - in Barton (1995) words - served to sell a product: monarchy. Why precisely this logo? After the winter solstice, shadows at noon become shorter, days become longer, and the azimuth of the rising sun decreases as the sun starts moving towards the opposite solstice. All these are "signs" which have been interpreted in uncountably many cultures as signals of rebirth, and therefore it is no surprise that Augustus' new era iconography was connected with the celestial icon of the winter solstice. Furthermore, Capricorn was also associated with fortune "lots" and was sometimes represented with a cornucopia.

At this point, it is quite clear that the orientation of Aosta to the winter solstice sunrise can be framed in a coherent picture. The town was in fact, and under all respect starting from the name, a "city of the founder", a place were Augustus was worshipped and Augustus' glory was exalted. The main ideology of Augustus' power was the advent of a new golden era, the main icon of the new era was the Capricorn, and the hierophany representing the celestial counterpart of the renewal on earth was the sun rising in Capricorn that is, the winter solstice. It is probably not by chance that Marcus Manilius tells us that the sign of Capricorn ruled all the western regions of the Empire (Manilius , Astronomica, IV 0.791 to 796) and that, as we have seen, both Augusta Praetoria and Augusta Emerita (Merida, Spain) incorporated an alignment to the winter solstice.

Given all this, we believe that the intentionality of the alignment of Aosta is proved beyond any doubt. Of course, it remains difficult to tell if midwinter was also the actual date of foundation of the town; what is likely, is that the astronomical orientation was a key ingredient of the dedicatory acts which were made to link the town to his ideal founder. To what extent these acts were suited to Augustus' propaganda it is also difficult to tell, and it is perhaps safer to assume the point of view of an homage to the ruler. In this respect, as mentioned, we also would like to propose - at least at the level of an educated guess - that Augustus' sign of rebirth was also explicitly alluded at in the corner block of the Balivi tower by sculpting a Capricorn on it (the relief and a standard representation of Capricorn are shown together in Fig. 16). We stress, however, that the results presented in this paper remain valid independently from this hypothesis.

\section{Discussion and conclusions}


Archaeoastronomy was born in the sixties of last century, with pioneering works on megalithic sites by Gerald Hawkings and Alexander Thom (see Ruggles 1999 and references therein). The main problem with many of these first researches was that "studying alignments" has no sense at all until the same alignments are shown to be due to the will of the builders of the monuments under exam; even after proving that, their interpretation still can be quite an hard task.

As a consequence, Archaeoastronomy took a long way to evolve in a quite complete discipline which today works in rigorous partnership with archaeology and takes into careful account all the possible sources of information (see e.g. Ruggles 2005, Magli 2013). The work presented here aroused exactly from one such situations: an archaeological discovery led us to investigate astronomical issues, which in turn furnished a quite coherent scenario for a better interpretation of the archaeological records. This scenario is the construction of Augustus' power trough intelligent use of a series of symbols and icons based on tradition, religion, and the legitimation of the ruler's rights trough an iconography related to the sky. In such an iconography a key role was played by Capricorn, the sign of the winter solstice, which fitted much better than Libra, the true Augustus' birth sign, with the idea of renewal traditionally associated with the midwinter sun. Within such a scenario we can frame all the new hints presented here: first of all, the clearly readable reliefs which appear on the upper - "noble" - register of the newly discovered block. These are the images of a plough and, on the adjacent side, that of a spade, both readable in succession in an anticlockwise direction. These clues clearly allude to the foundation ritual of the town, direct "replica" of the mythical one of Rome, which was in turn a key ingredient of Augustus' propaganda. The second new hint presented here is the orientation of "newborn" Augusta to the sun rising on the winter solstice, and therefore in the adoptive sign of her ideal founder, the Capricorn, which - we propose - is also probably represented in the block.

Interestingly enough, relationships between astronomical orientation and "horoscopes" are recently emerging also from the Hellenistic world, for instance at Alexandria and Seleucia on the Tigris (see Ferro and Magli 2010 and references therein) and on the funerary monument of Antiochos I, King of Commagene, at Mount Nemrud (Belmonte and García 2010). The astronomical orientation of Augusta Praetoria was thus likely conceived to put in further evidence the relationship of the town with Augustus, by means of a fascinating appointment between the midwinter sun and the rigorous geometry of the urban layout of the town, framed within the stunning scenario of the Italian Alps; this appointment is regularly attended still today.

In a quite precise sense, then, we can say that Aosta was born under Augustus' sign. 


\section{Acknowledgements}

The research presented here has been made possible by the continual support of the Soprintendenza per $i$ beni e le attività culturali of Regione Autonoma Valle d'Aosta. In particular the authors gratefully acknowledge the superintendent Architect Roberto Domaine and the director for restoration and promotion, Architect Gaetano De Gattis. G.M. further acknowledges support by FARB (University fund for basic research) at the Politecnico of Milan.

Stella Vittoria Bertarione, Soprintendenza per i beni e le attività culturali, Regione Autonoma Valle d'Aosta, Ufficio Beni archeologici Piazza Roncas, 12, 11100 Aosta, Italy. s.bertarione@regione.vda.it

Giulio Magli, Faculty of Civil Architecture, Politecnico di Milano Piazza Leonardo da Vinci 32, 20133 Milano, Italy.giulio.magli@polimi.it

\section{AUTHOR'S BRIEF CV}

Stella Bertarione is Archaeologist at the Superintendence to Cultural Heritage of Regione Autonoma Valle d'Aosta, Italy. After graduating in Classics at the University of Pisa, she specialized on Classical Archaeology at the Padova University. She has participated to several archaeological surveys and excavations on Roman and Punic sites, publishing several papers, as well as being responsible of preventive excavations in Valle d'Aosta on behalf of the Superintendence. She is also in charge of the communication and promotion of cultural heritage office, at the tourism department of the Valle d'Aosta region.

Giulio Magli is Full Professor at the Faculty of Civil Architecture of the Politecnico di Milano, where he teaches the unique Archaeoastronomy course ever established in an Italian university. He holds a PhD in Mathematical Physics, but his research today focuses on Archaeoastronomy and the relationship between architecture, landscape and astronomy in ancient Egyptian, Inca and Mediterranean cultures. In addition to his many papers in this field, he is the author of the books "Mysteries and Discoveries of Archaeoastronomy" (Springer Verlag, 2009) and "Architecture, Astronomy and Sacred Landscape in Ancient Egypt" (Cambridge University Press, 2013). His researches in archaeoastronomy have been reported several times in National Geographic, Discovery News and on CNN. 


\section{References}

Aveni, A. and Capone, G. 1985: Possible Astronomical Reference in the Urban

Design of Ancient Alatri, Lazio, Italy. Archaeoastronomy 8, 12.

Aveni, A. and Romano, G. 1994: Orientation and Etruscan Ritual. Antiquity 68, 54563.

Barton, T. 1995 Augustus and Capricorn: Astrological Polyvalency and Imperial Rhetoric. The Journal of Roman Studies, Vol. 85, pp. 33-51

Belmonte J.A., and Gonzalez Garcia, C. 2010. Antiochos's hierothesion at Nemrud Dag revisited: adjusting the date in the light of astronomical evidence. JHA 41, 469481.

Bertarione, S.V. 2013: Indagini archeologiche alla Torre dei Balivi. Si svela la sanctitas murorum. In: BSBAC, 9, 2012, at press.

Buchner, E. 1976 Solarium Augusti und Ara Pacis, RM 83 319-65

Candidi Dionigi, M. 1809 Viaggio in alcune città del Lazio che diconsi fondate dal re Saturno (reprint 2002, Tofani Editore, Alatri)

Castagnoli, F. 1971: Orthogonal town planning in antiquity. Cambridge, CUP.

Carandini, A. (1983) A.Carandini, Cartagine romana. Breve storia di una periferia urbana [50-58]in

S. Settis (Ed.), Misurare la terra. Centuriazione e coloni nel mondo romano,Panini, Modena, 1983.

Carandini A, Cappelli, R. 2000: Roma, Romolo, Remo e la fondazione della città, Electa, Rome

Chevallier R. Caillemer, A. 1954 Les centuriations de l'« Africa vetus » Annales. Économies, Sociétés, Civilisations 9, 433-460

Condos, P (1997). Star Myths of the Greeks and Romans: a Sourcebook. Grand Rapids: Phanes Press. 
Decramer, L. and Hilton, R. 1998: Nouvelles recherches sur la grande centuriation de l'Africa Nova. Cahiers de Métrologie 16, 5-50.

Decramer, L., Hilton, R. and Plas, a. 2001: Centuriations et orientation solaire. Les bornes gromatiques de Tunisie. In La mesure des longues distances dans le cadre des limitations antiques (Paris, CNRS).

Ferro, L. and Magli, G. 2012: The Astronomical Orientation of the Urban Plan of Alexandria. Oxford Journal of Archaeology 31, 381-389,

Galinsky K. 2005 The Cambridge Companion to the Age of Augustus. Cambridge University Press, Cambridge.

Giovenale, G. (1899) I monumenti preromani del Lazio. Atti Pont. Acc. Arch. p.1-53

González García, C., Rodríguez Antón, A., and Belmonte, J.A. (2014) The orientation of roman towns in Hispania: preliminary results. MAA, at press.

Gonzalez Garcia, C., Costa-Ferrer, L, 2011 The diachronic study of orientations: Merida as case study. In: Ruggles C (ed) Archaeoastronomy and ethnoastronomy: building bridges between cultures. Cambridge University Press, Cambridge, 374-383

Gonzalez Garcia, C., Magli, G. 2012: Roman City Planning and Spatial Organization To appear in Ruggles, C. (ed.) Handbook of Archaeoastronomy and Ethnoastronomy, Springer Verlag, NY.

Hannah R 2009 The Pantheon as a timekeeper. British Sundial Society Bulletin 21(4):2-5

Hannah R 2009b Seasonal Liminality in the Horologium Augusti 30th Australasian Society for Classical Studies Conference (ASCS)

Hannah R, Magli G 2011 The role of the sun in the Pantheon design and meaning. Numen 58:486-513

Haselberger, L. (2011) A debate on the Horologium of Augustus: controversy and clarifications (with responses by P. J. Heslin and M. Schütz and additional remarks by 
R. Hannah and G. Alföldy). Journal Of Roman Archaeology 24, 47-96.

Heslin, P. 2007 Augustus, Domitian and the So-called Horologium Augusti,' JRS 97 $1-20$.

Le Gall, J. 1975: Les romains et l'orientation solaire. MEFRA 87(1), 287-320

Laur-Belart, R (1973) Führer durch Augusta Raurica, Augst, Basel

Laurence, R., Cleary, S.E, Sears, G. (2011) The city in the Roman West, Cambridge University Press, Cambridge.

Liritzis, I and Castro, B. Delphi and cosmovision: Apollo's absence at the land of the hyperboreans and the time for consulting the oracle. Journal of Astronomical History and Heritage, 16, 184-206 (2013).

Lugli, G. 1957 La tecnica edilizia romana con particolare riguardo a Roma e al Lazio, Bardi, Roma.

Magli, G. 2006: The Acropolis of Alatri: astronomy and architecture. Nexus Network Journal-Architecture and Mathematics 8, 5-16.

Magli, G. 2007: Non-orthogonal features in the planning of four ancient towns of Central Italy. Nexus Network Journal - Architecture and Mathematics 9(1), 71-92.

Magli G 2008 On the orientation of Roman towns in Italy. Oxford Journal of Archaeology 27(1):63-71

Magli, G. 2013 Architecture, Astronomy and Sacred Landscape in Ancient Egypt Cambridge University Press, Cambridge.

Marques de Faria A (2001) Pax Iulia, Felicitas Iulia, Liberalitas Iulia. Rev. Port. Arqueol. 224 4(2): 351-362

Martini R. 2002, Monete romane imperiali contromarcate di bronzo dall'area delle province della Moesia e della Pannonia di I secolo d.C., vol. 1, parte 1; IDEM, Tipologia delle contromarche, parte 2, Milano, Collezioni numismatiche, 2002 
Martini R. 2003, Collezione Pangerl. Contromarche imperiali romane (AugustusVespasianus). The Pangerl Collection. Catalog and Commentary on Countermarked Roman Imperial Coins, Milano, Nomismata, 2003

Mateos Cruz, P. (2001). Augusta Emerita. La investigación arqueológica en una ciudad de época romana.Archivo Español de Arqueología 74(183-184)

Mollo R 1982a, Augusta Praetoria. Aggiornamento sulle conoscenze archeologiche della città e del suo territorio, in Atti del Congresso sul Bimillenario della città di Aosta (Aosta 5-20 ottobre 1975), Bordighera 1982, pp.205-315;

Mollo R 1982b, Augusta Praetoria ed il suo territorio, in Archeologia in Valle d'Aosta. Dal Neolitico alla caduta dell'Impero romano 3500 a.C. - V sec. d.C., catalogo della mostra (Saint-Pierre, castello Sarriod de La Tour, agosto 1981 - ottobre 1991 ), Quart 1982, pp. 63-138;

Mollo R 1987, Aosta romana. Introduzione, in M. CUAZ (a cura di), Aosta. Progetto per una storia della città, Quart 1987, 19-70;

Mollo R 1988, La stratificazione archeologica di Augusta Praetoria, in Archeologia stratigrafica dell'Italia settentrionale, Atti del Convegno (Brescia, 1 marzo 1986), 1, Como 1988, pp. 74-100;

Mollo R 1995, Augusta Praetoria (Aosta): il complesso forense, in M. MIRABELLA ROBERTI (a cura di), "Forum e Basilica" in Aquileia e nella Cisalpina romana, "Antichità Altoadriatiche", XLII, 1995, pp. 411-431;

Mollo R 1999, Il complesso forense di Augusta Praetoria (Aosta). Problematiche, realtà e prospettive, in M. BARRA BAGNASCO, M.C. CONTI (a cura di), Studi di archeologia classica dedicati a Giorgio Gullini per i quarant'anni di insegnamento, Torino 1999, pp. 97-119;

Mollo R 2000, L'organizzazione del suburbio di Augusta Praetoria (Aosta) e le trasformazioni successive, in M.V. ANTICO GALLINA (a cura di), Dal suburbium al faubourg: evoluzione di una realtà urbana, Itinera, Milano 2000, pp. 149-200; 
Mollo R 2004, Augusta Praetoria (Aosta) e l'utilizzazione delle risorse idriche: città e suburbio, in M.V. ANTICO GALLINA, Acque per l'utilitas, per la salubritas, per l'amoenitas, Itinera, Milano 2004, pp. 59-137;

Mollo R 2012, Aosta, in P. ZANKER, H. VON HERSBERG, Storia dell'architettura italiana. Architettura romana. Le città in Italia, Milano 2012, pp. 396-437.)

Pollard, N. and Berry, J. (2012) The Complete Roman Legions Thames \& Hudson; London.

Ramsey, J. T. and A. Lewis Licht. 1997. The Comet of 44 B.C. and Caesar's Funeral Games. Atlanta: Scholars Press.

Rehak, P. 2006. Imperium and Cosmos: Augustus and the Northern Campus Martius. Madison, Wisconsin: The University of Wisconsin Press.

Ruggles, C.L.N. 1999. Astronomy in Prehistoric Britain and Ireland. New Haven, CT: Yale University Press.

Rykwert J 1999 The idea of a town: the anthropology of urban form in Rome, Italy, and the ancient world. MIT Press, Cambridge

Salt A. and Boutsikas, E. Knowing when to consult the Oracle at Delphi, Antiquity 79 (2005) 564-72)

Sarris, A., Teichmann, M., Seferou, P., Kokinou, E.(2010) Investigation of the UrbanSuburban Center of Ancient Nikopolis (Greece) through the Employment of Geophysical Prospection Techniques. Proc. 38th Annual Conference on Computer Applications and Quantitative Methods in Archaeology, F. Contreras, M. Farjas and F.J. Melero (eds.)

Torelli and Gros (1988) Storia dell'urbanistica. Il mondo Romano.

Wilson and Quinn (2013) Journal of Roman Studies 103, pp. 117-173.

Zanker, P. 1990: The Power of Images in the Age of Augustus. The University of Michigan Press; 


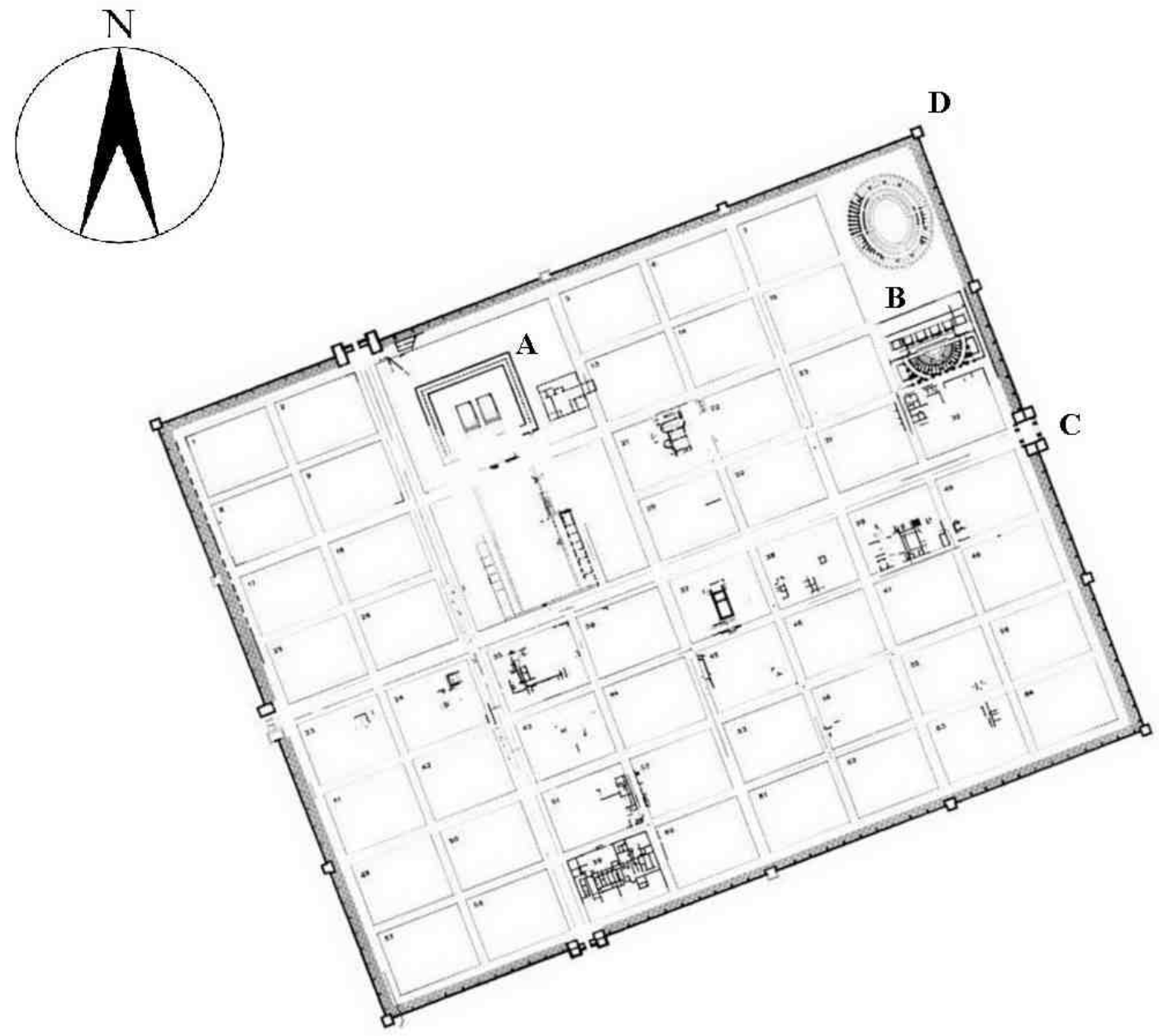

Fig. 1. Schematic plan of Augusta Praetoria Salassorum, Roman Aosta.

A) Twin temples and forum B) Amphitheatre and Theatre C) Porta Praetoria D) Balivi Tower 


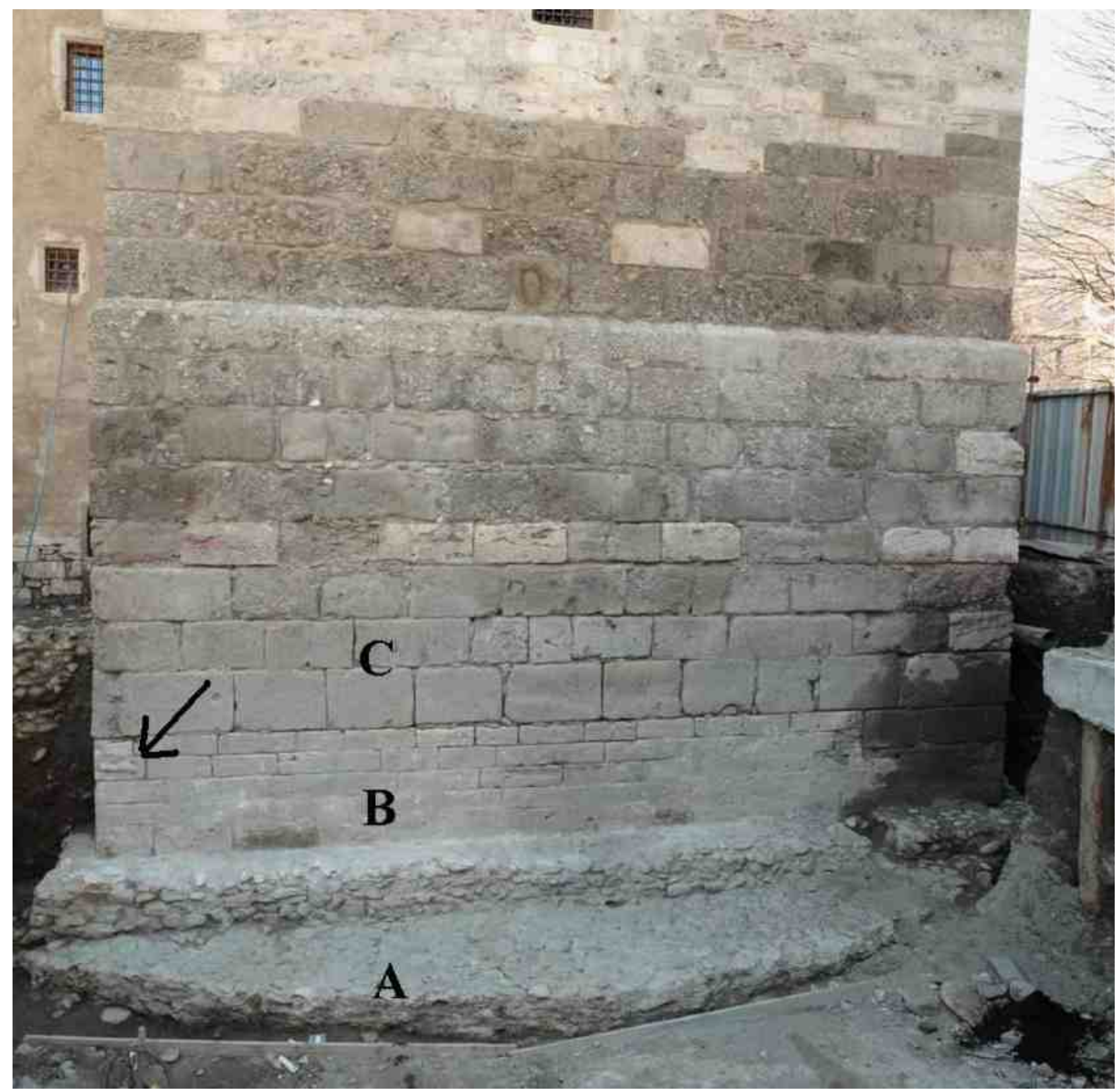

Fig. 2 Aosta. The Balivi tower at the end the recent excavations, viewed from the east. From the lower level, A) circular platform of foundation B) Roman travertine layers C) Middle Age Layers. The newly discovered block is indicated by an arrow. (Photograph S. E. Zanelli) 


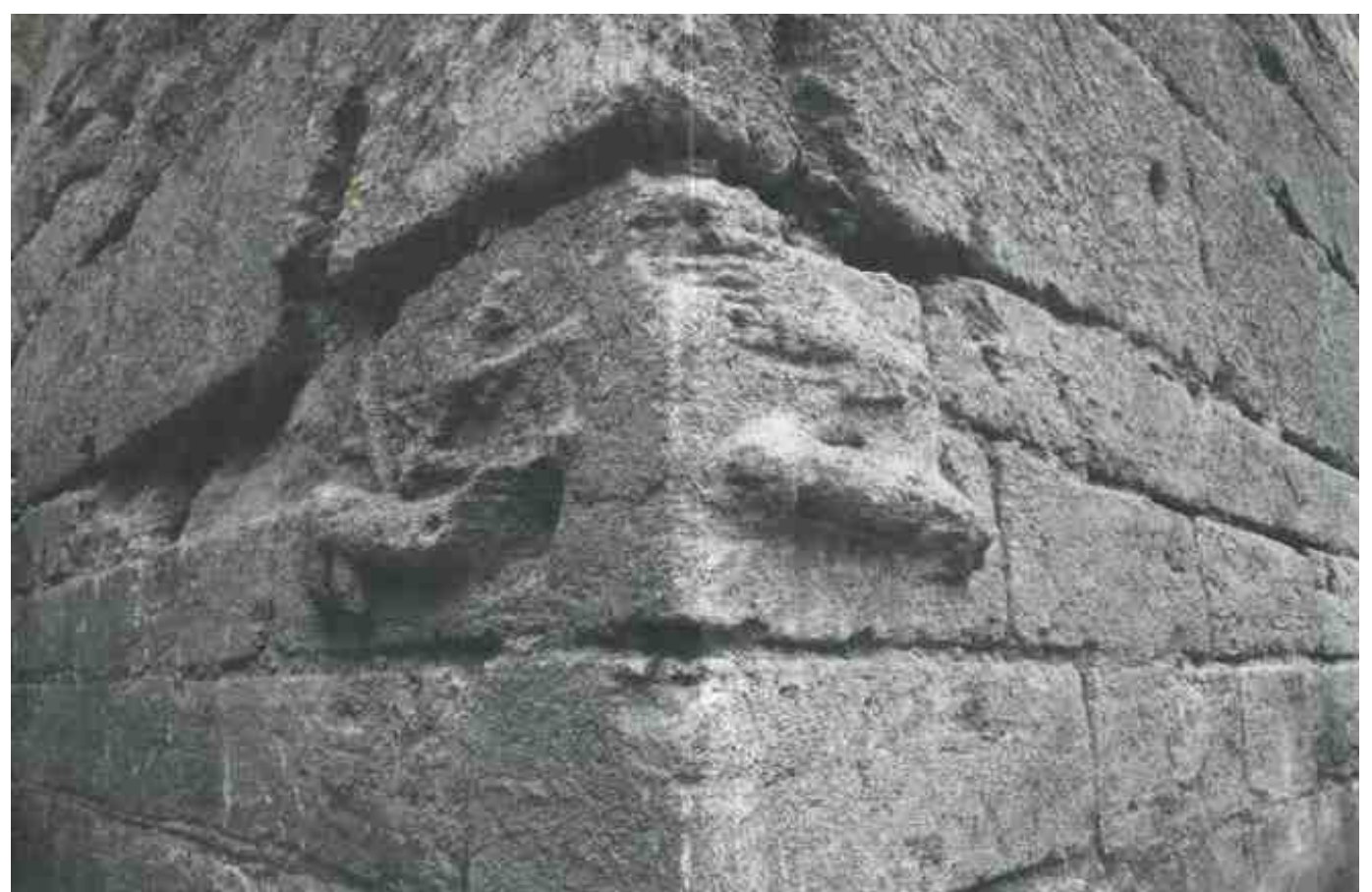

Fig. 3 Aosta. The corner block discovered on the Balivi Tower, front view. (Photograph L. Bornaz) 


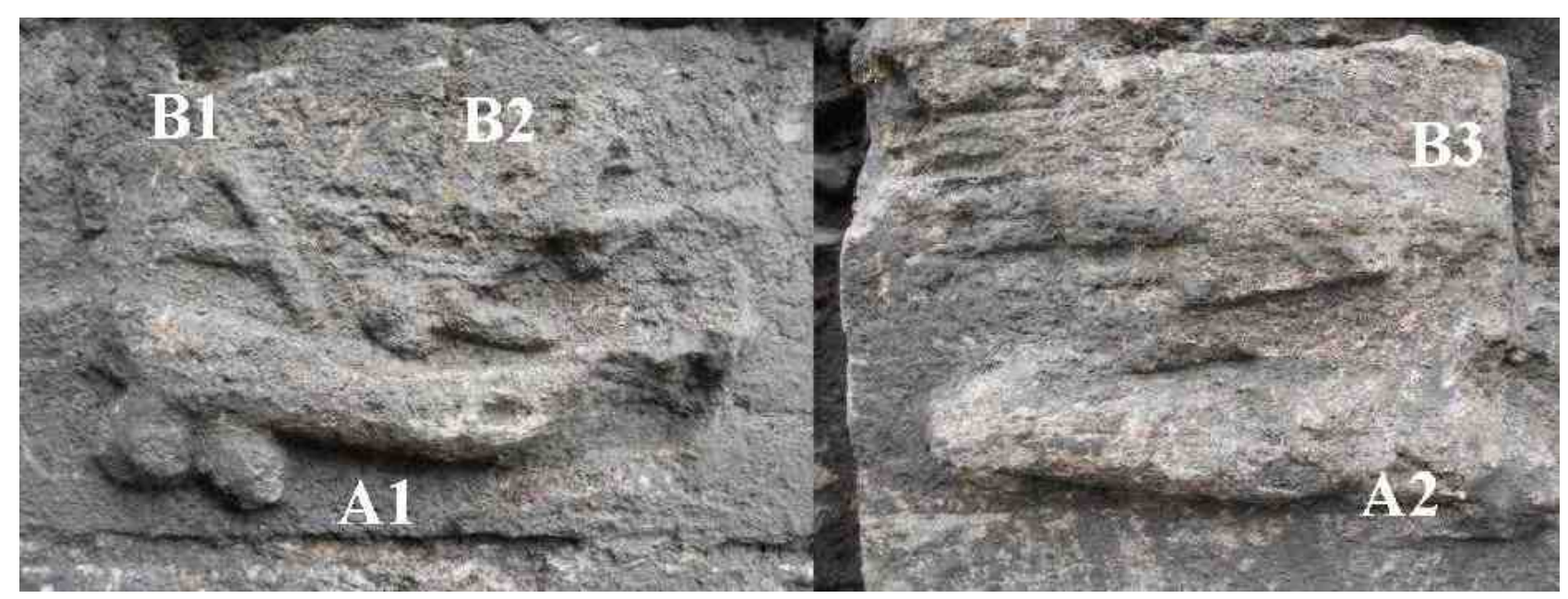

Fig. 4 Aosta. The reliefs on the newly discovered corner block. (Photographs S. E. Zanelli) 


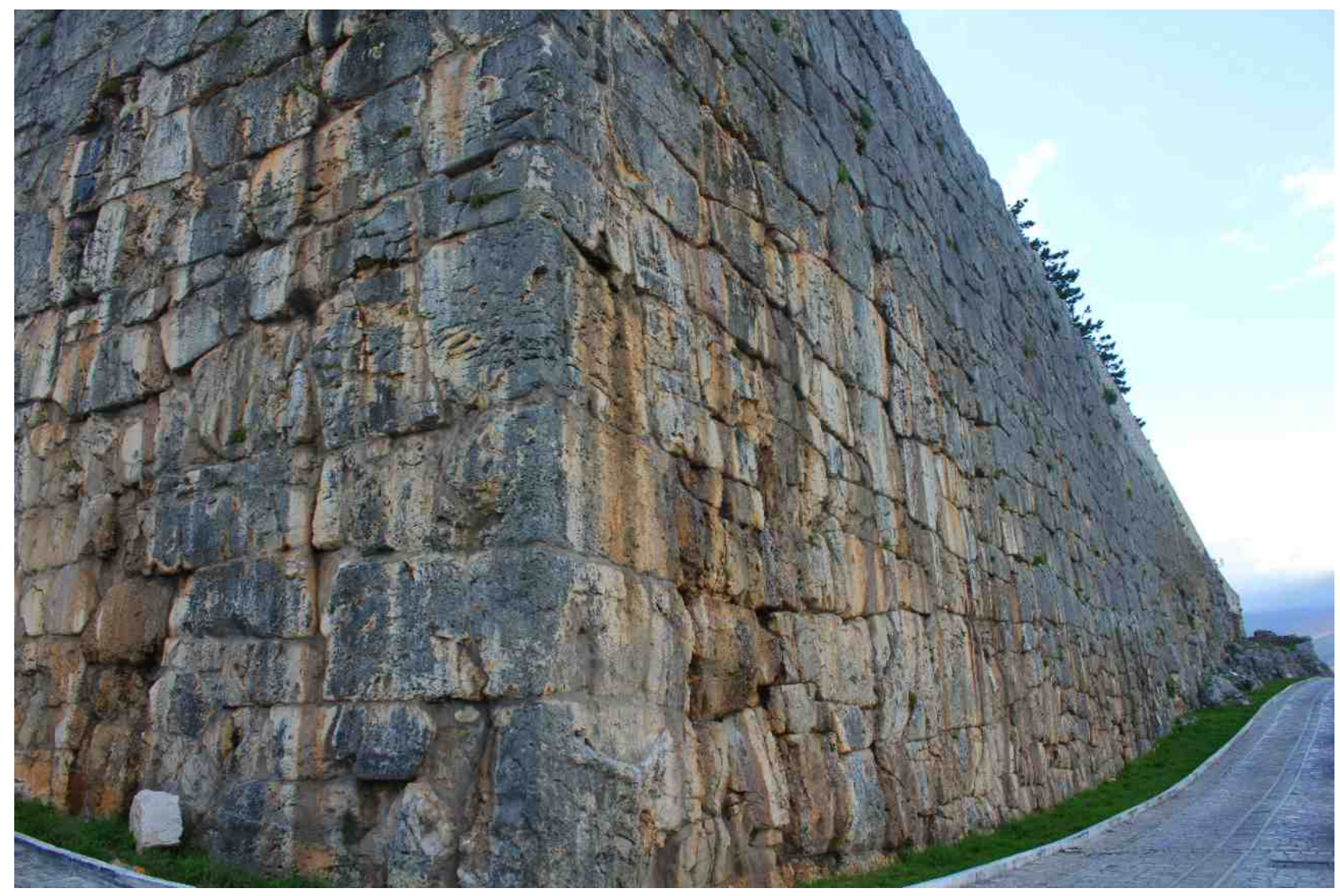

Fig. 5. Alatri. The south-east corner of the Acropolis with the corner block relief at the basis. (Photograph G. Magli) 


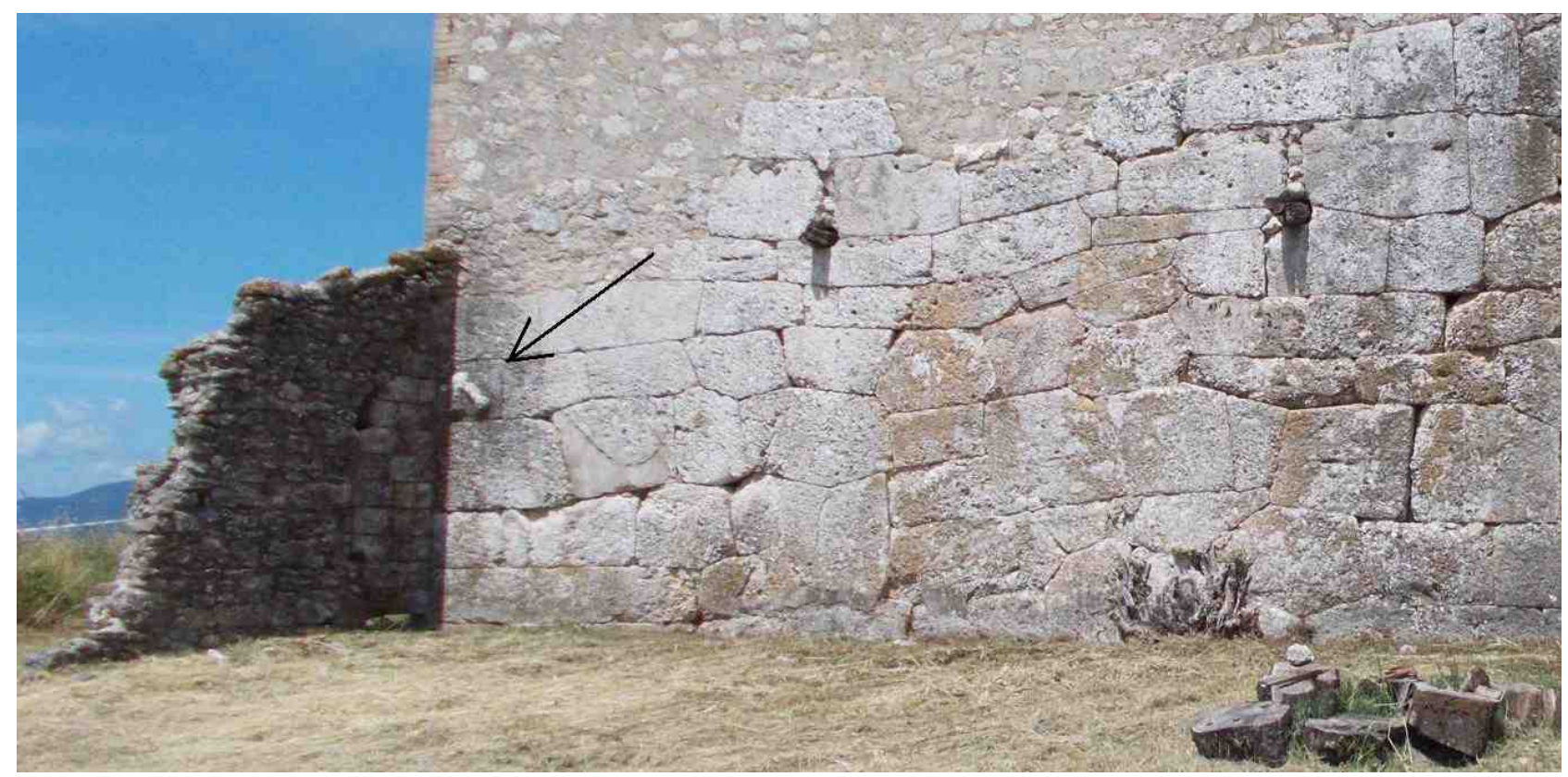

Fig. 6. Grotte di Torri in Sabina (Rieti). The north-west corner of the polygonal walls seen from the west, with the corner block with reliefs evidenced by an arrow. The remains of an orthogonal wall of small stones come from a later addition. (Photograph G. Magli) 

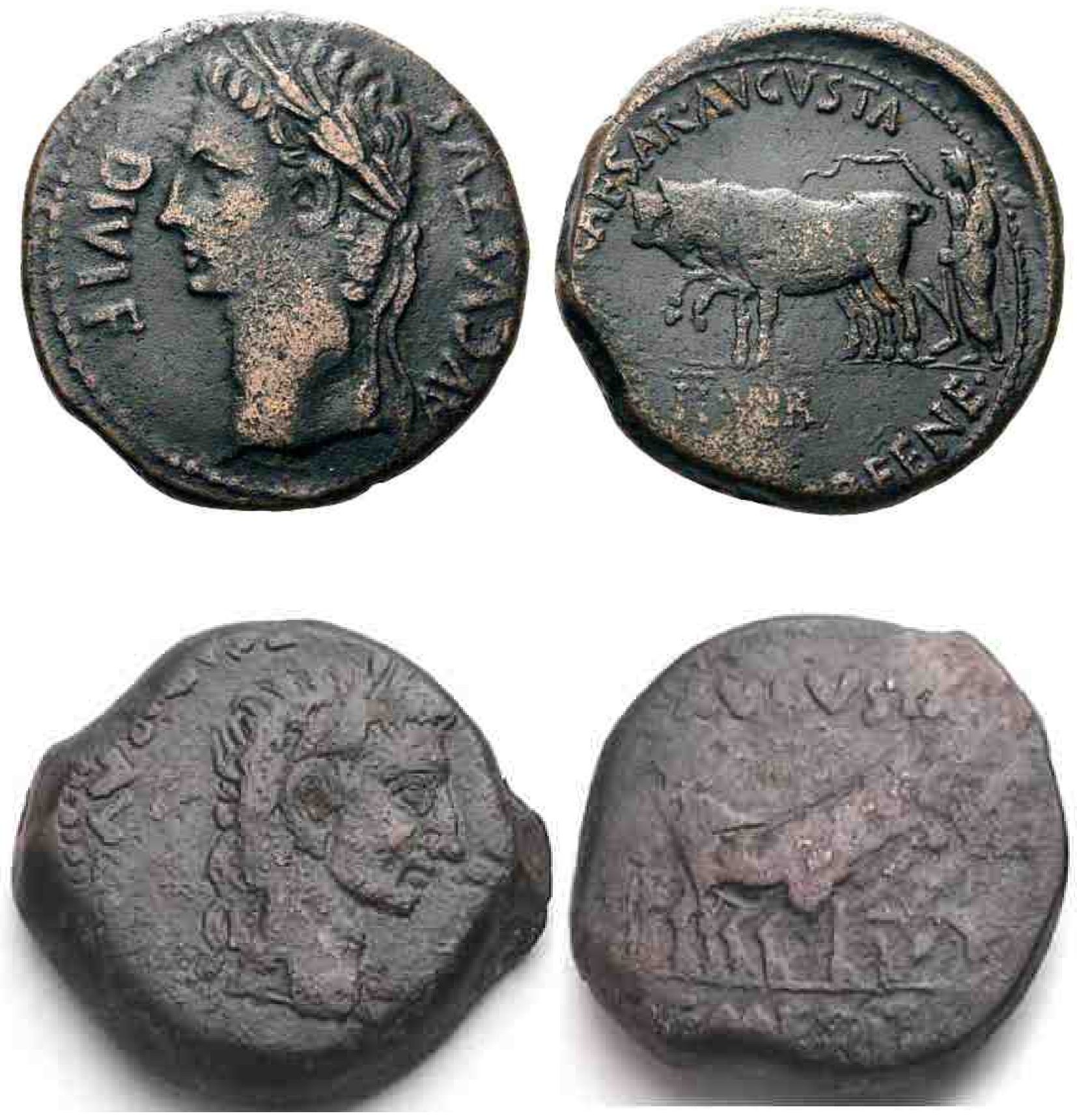

Fig. 7. Two Augustan coins from Caesaraugusta (up) and Merida (down) showing ritual ploughing on the recto. (Images in the public domain) 


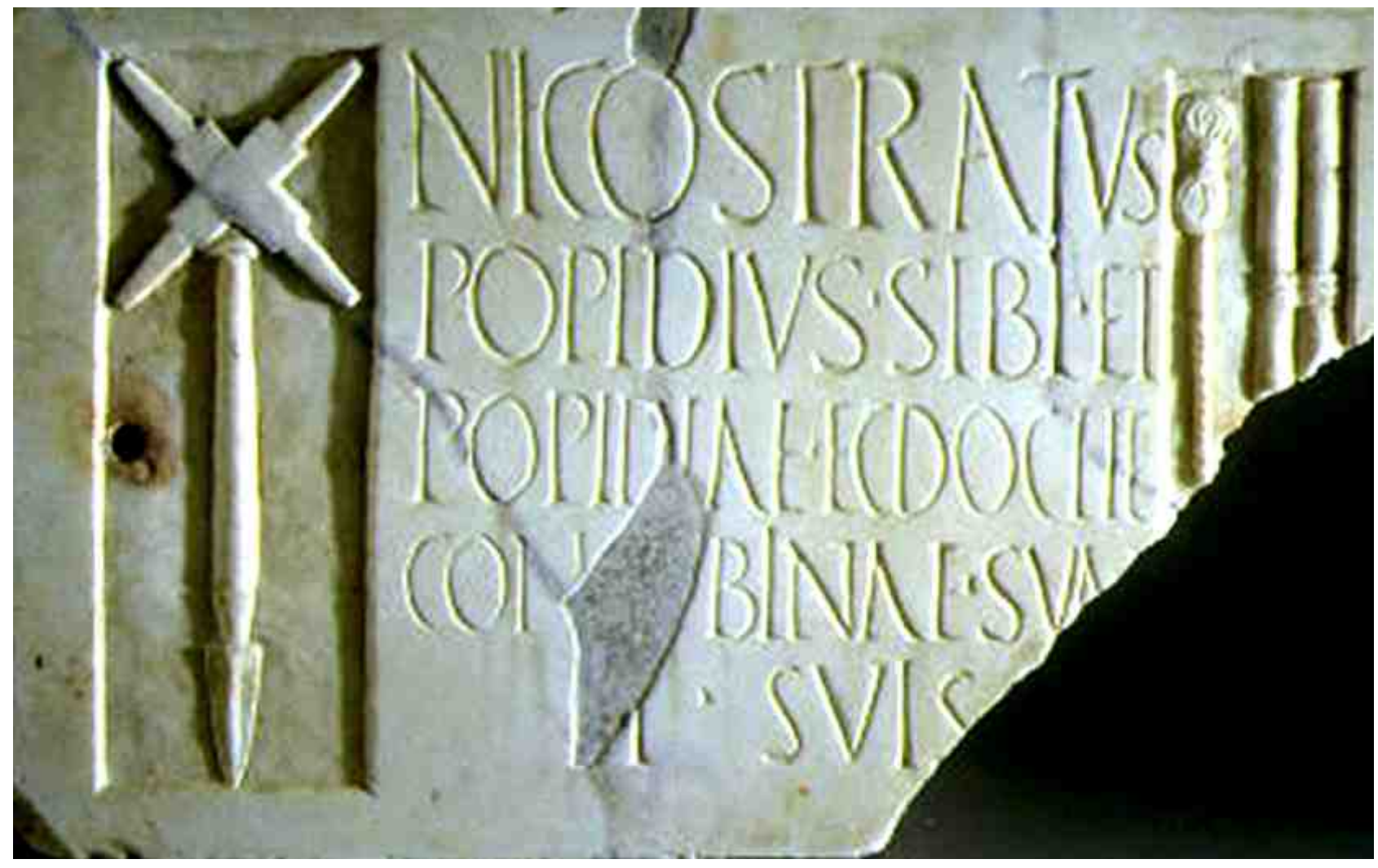

Fig. 8. The tomb slab of the Gromaticus Popidius Nicostratus, from Pompeii. Notice the spade at the basis of the Groma's pole on the left (Boscoreale, Antiquarium. Photograph G. Magli) 


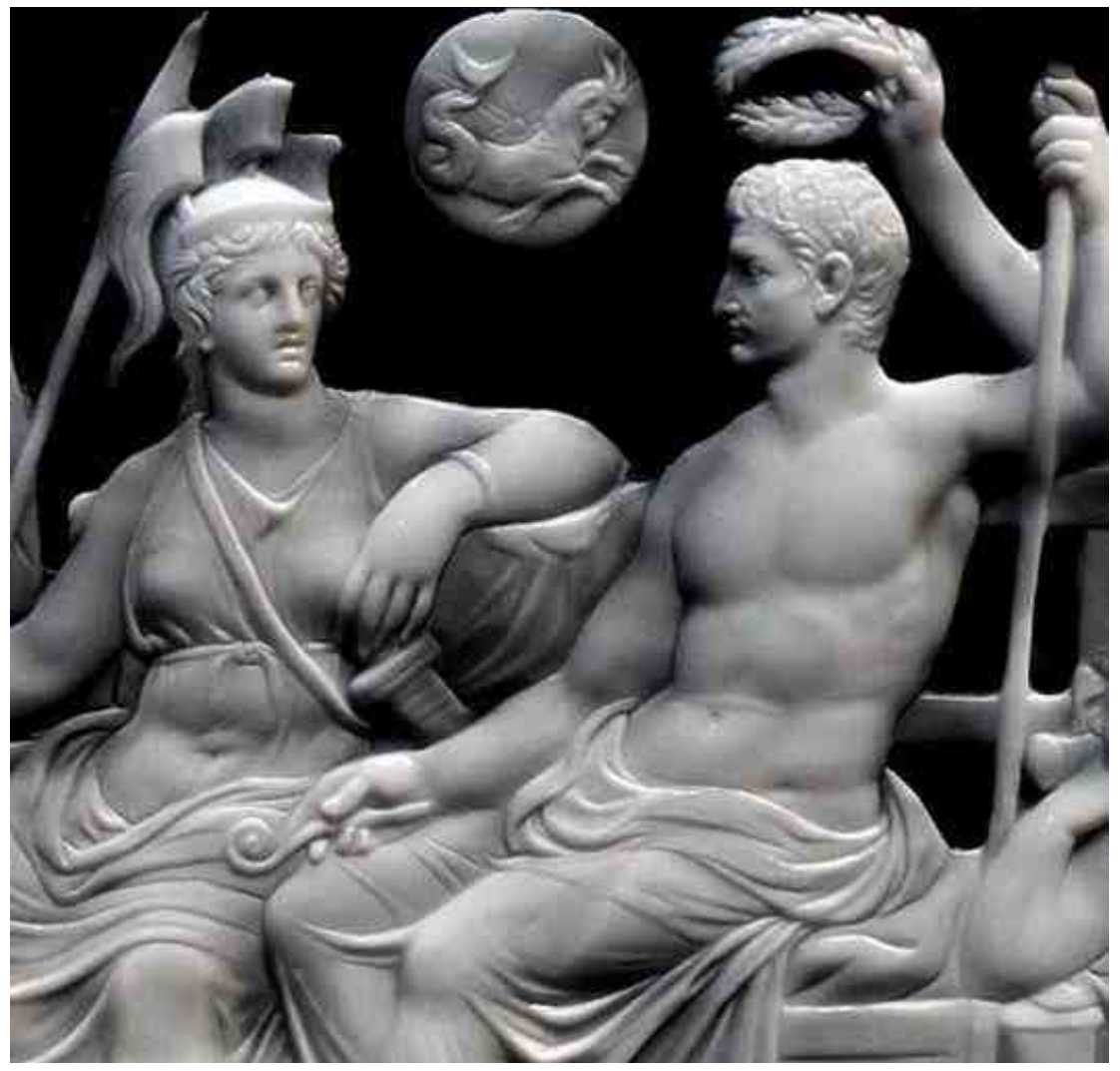

Fig. 9. Gemma Augustea ( Kunsthistorisches Museum, Vien). Detail of the upper register showing Augustus crowned, handling a lituus and seated as Jupiter. On the left, the figure of deified Rome is looking at him. Between the two fluctuates a sphere, or disk, containing a star and the Capricorn. (Adapted from an image in the public domain) 


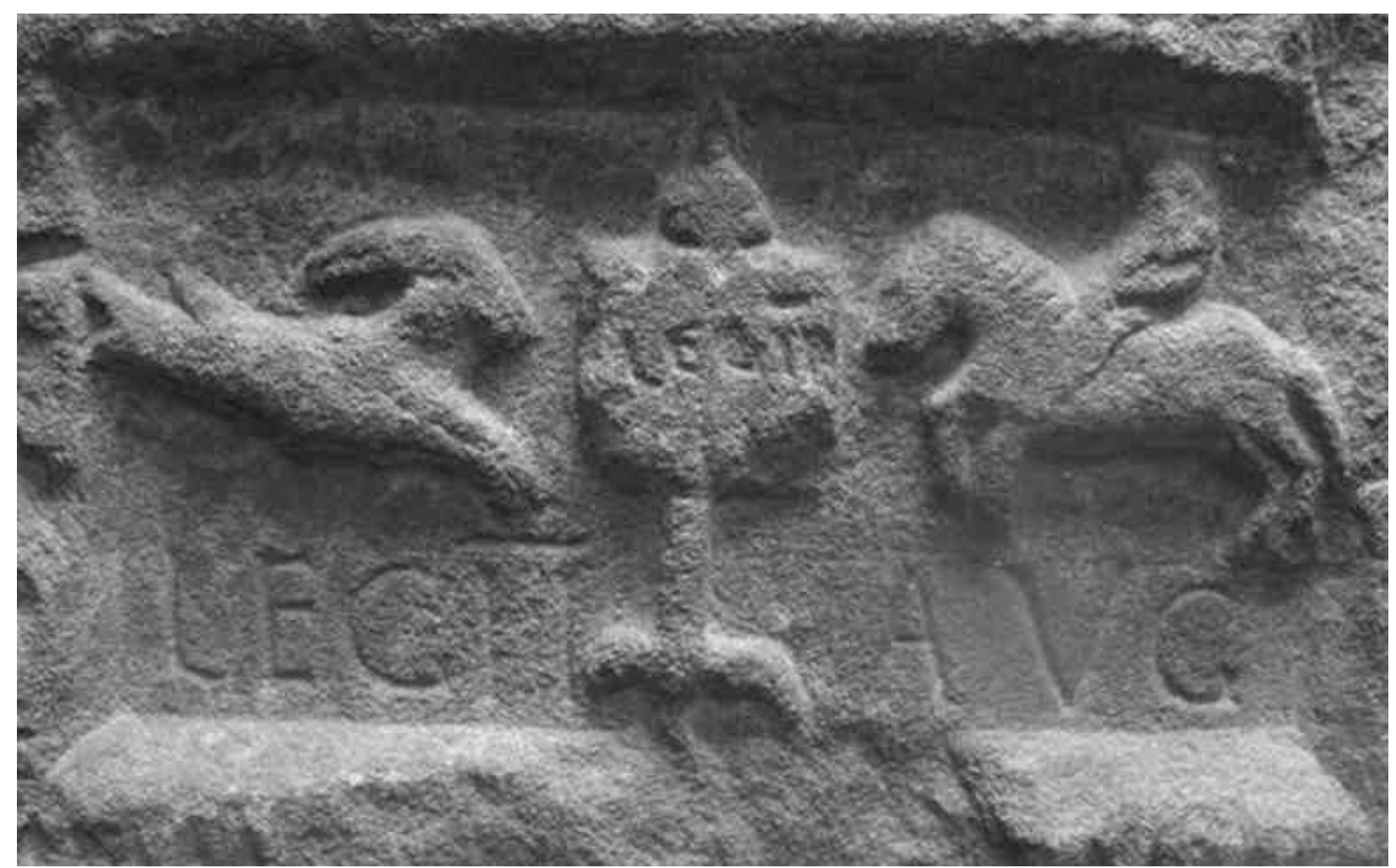

Fig. 10 A stone relief of Legio II Augusta from Hadrian's wall, showing a Capricorn (left) and Pegasus (right) as emblems (British Museum, photograph by the authors) 

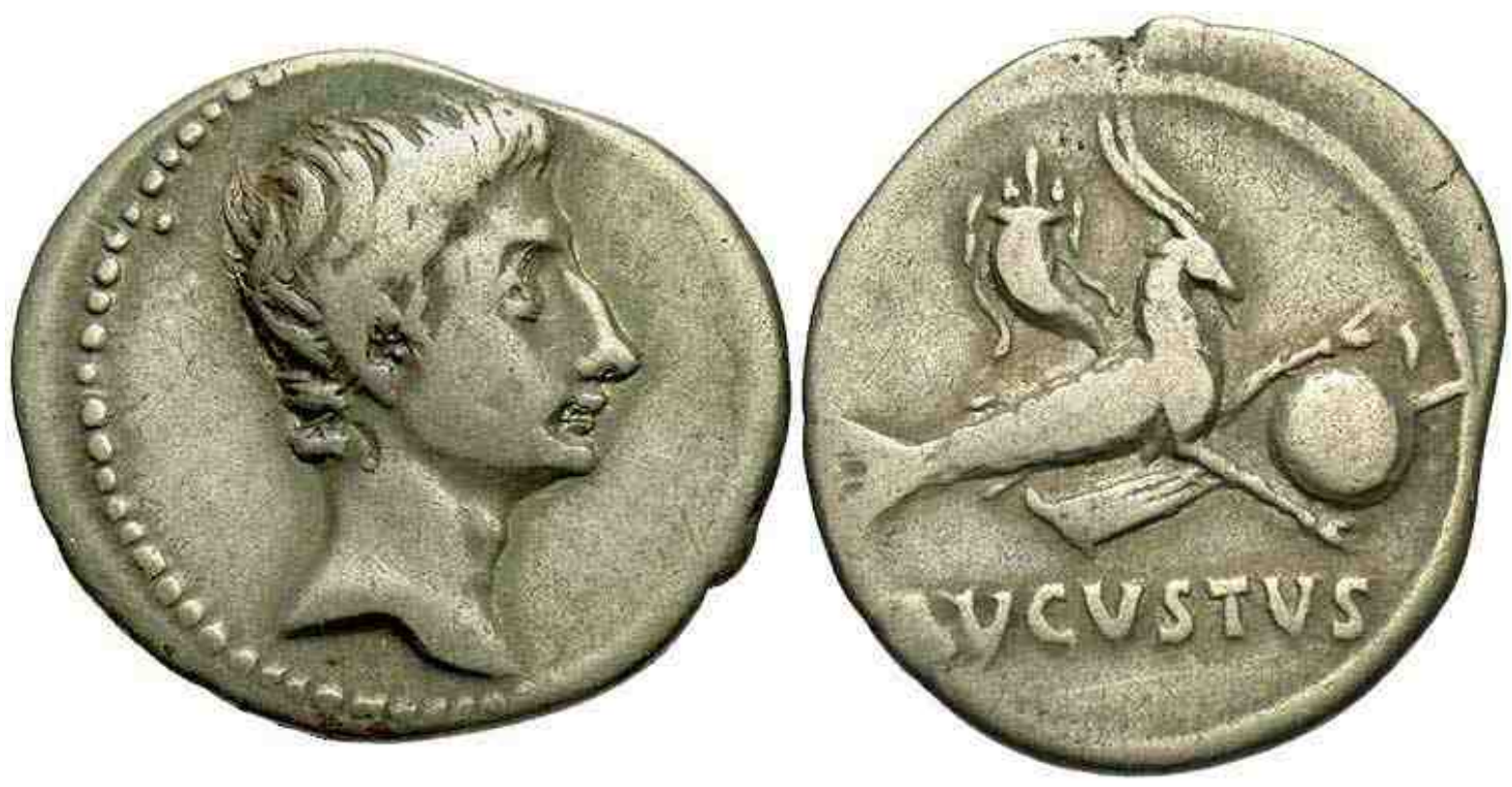

Fig. 11. Denarius issued in Spain around 16 BC. Augustus (left) and the Capricorn carrying a Globus and a Cornucopia above the back (right). (Image in the public domain). 

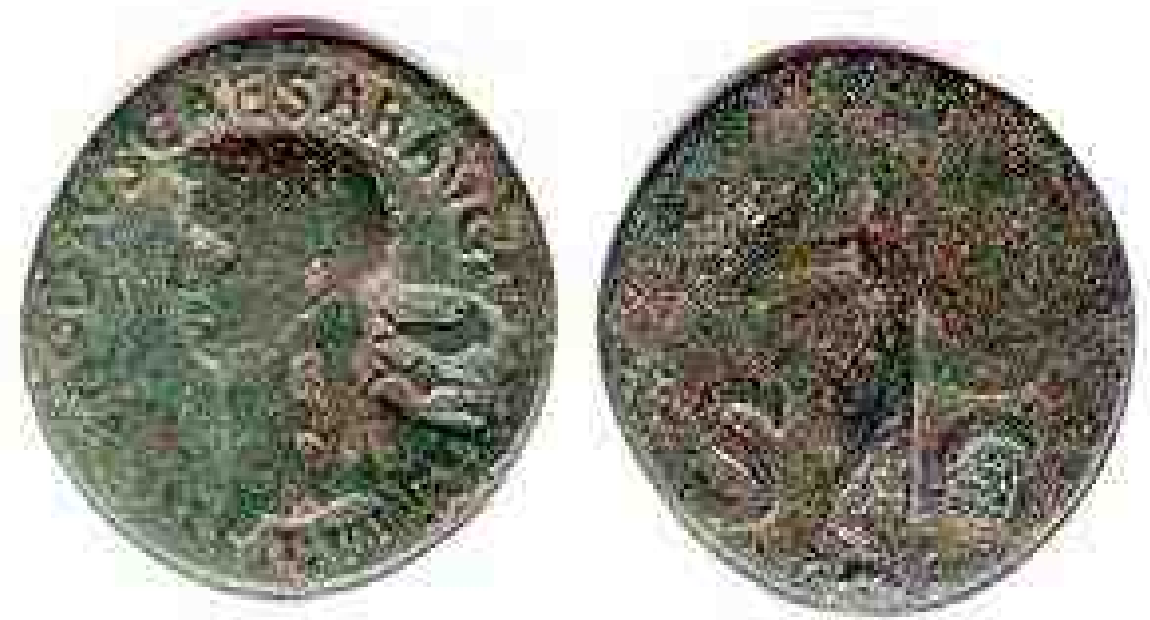

Fig. 12. Sestertius by Claudius. The recto brings a counter mark with a Capricorn and a plough. 


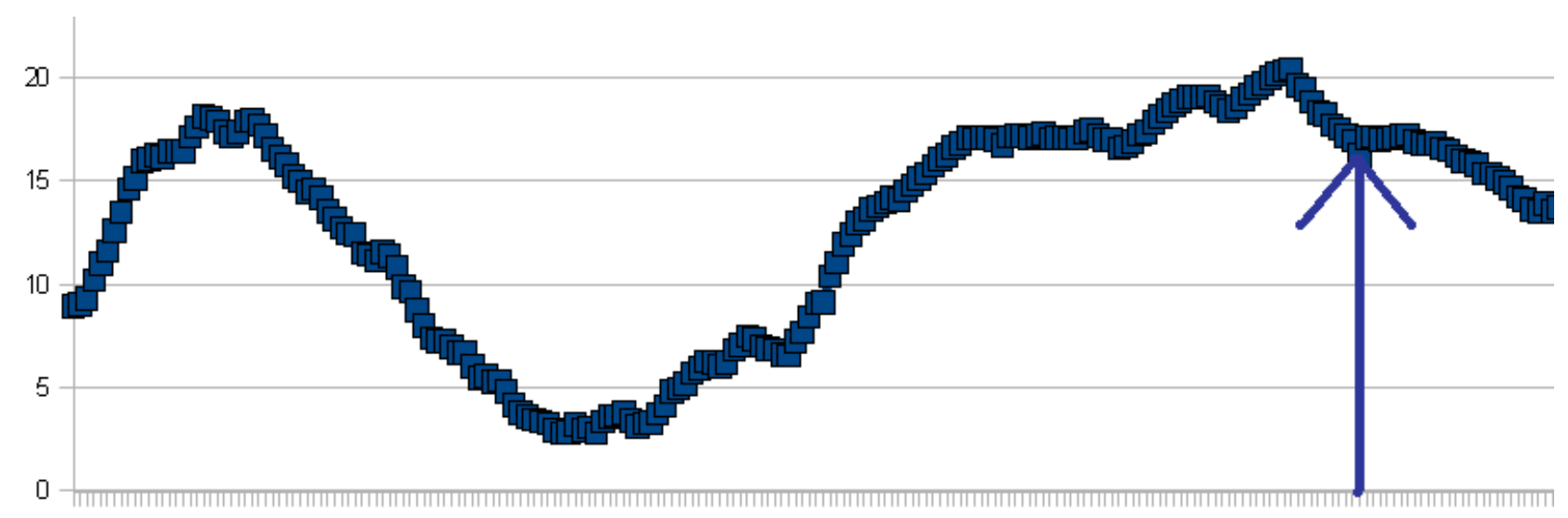

Fig. 13. The profile of the eastern horizon as seen from the center of Aosta (azimuths $0-180^{\circ} \mathrm{vs}$. altitudes in degrees) reconstructed from theodolite data. The arrow corresponds to the azimuth of the Kardo at $158^{\circ}$. 
Fig. 14. Aosta. Computer reconstruction of the sun rising in Capricorn at the winter solstice, $25 \mathrm{BC}$. The sun is shown at an altitude of $\sim 17^{\circ}$, when it is first visible along the Kardo of the town

(simulation by the authors with Starry Night Pro software). 


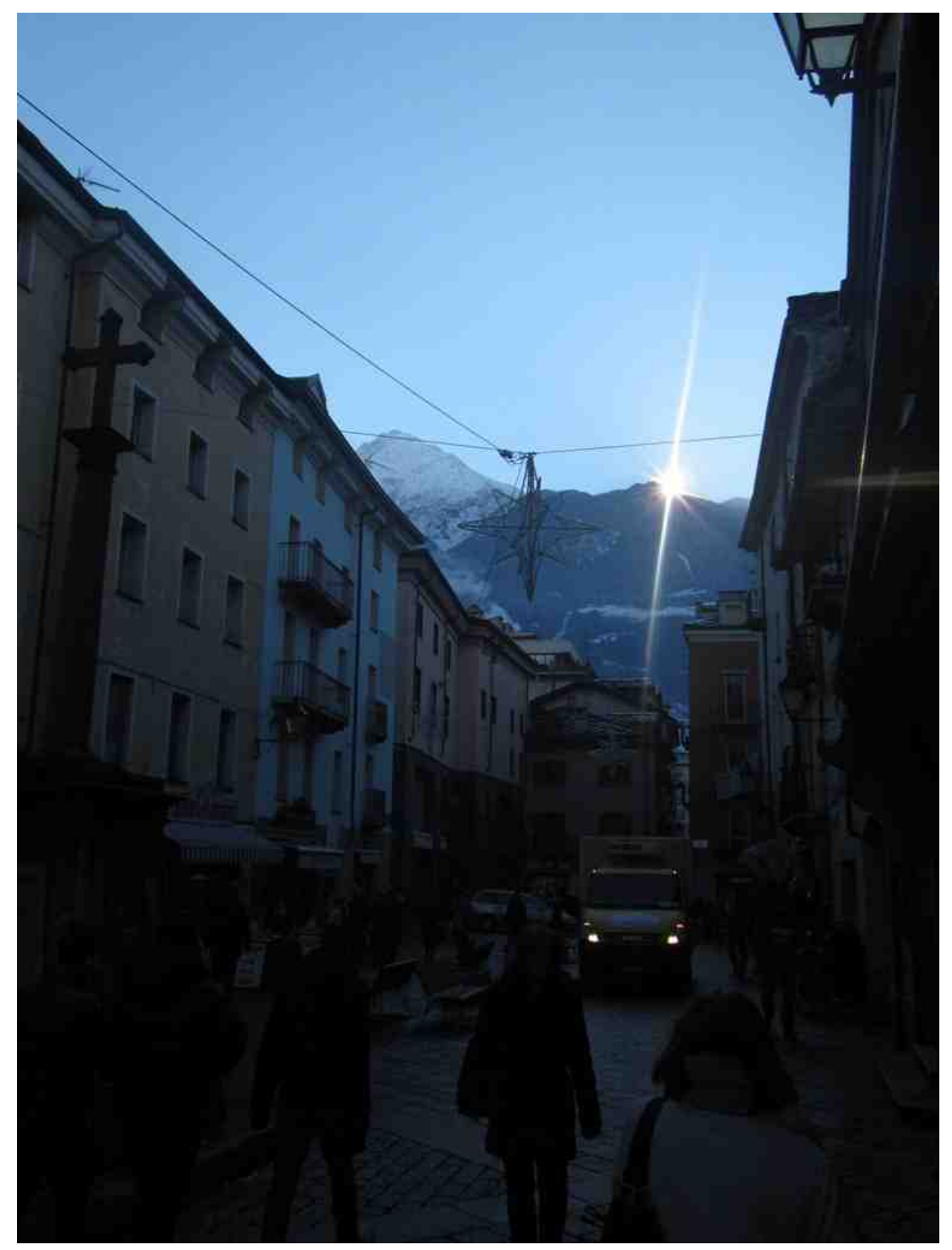

Fig. 15.

Aosta, winter solstice 2013, $10.41 \mathrm{am}$. The sun rises still in almost perfect alignment with the Kardo, in a picture taken from the cross-center of the town (Photograph by Paolo Pellissier) 

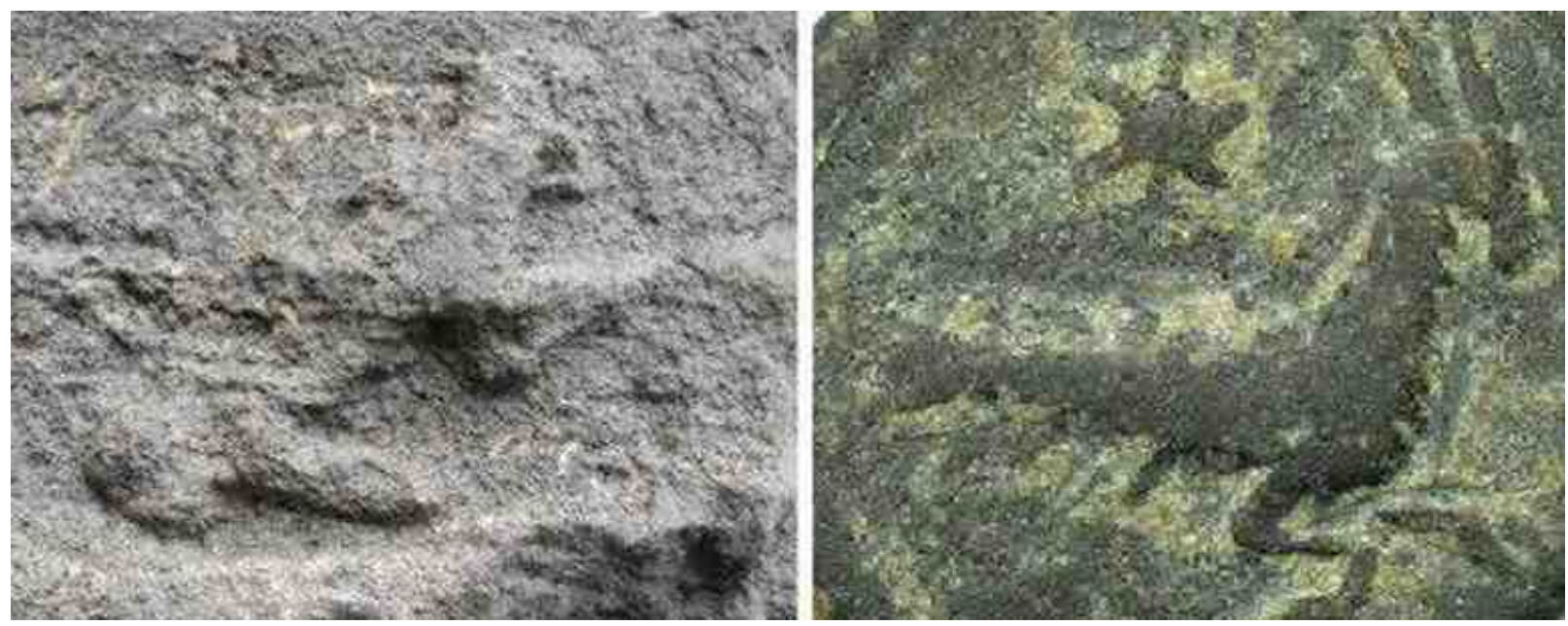

Fig. 16. The image of Capricorn on a coin of Augustan period (right) and a closeup of the relief $B 2$ of the corner block on the Balivi tower (left). (Left: photograph S. Bertarione; right: adapted from image in the public domain). 